https://helda.helsinki.fi

Occurrence of the moth Cydia pactolana is associated with the spruce canker fungus Neonectria fuckeliana

\title{
Uimari, Anne
}

2018

Uimari , A , Heliövaara , K, Tuba , K , Poteri , M \& Vuorinen , M 2018 , ' Occurrence of the moth Cydia pactolana is associated with the spruce canker fungus Neonectria fuckeliana ' ,

Scandinavian Journal of Forest Research , vol. 33 , no. 6 , pp. 529-534 . https://doi.org/10.1080/02827581.2018.142

http://hdl.handle.net/10138/298454

https://doi.org/10.1080/02827581.2018.1427791

acceptedVersion

Downloaded from Helda, University of Helsinki institutional repository.

This is an electronic reprint of the original article.

This reprint may differ from the original in pagination and typographic detail.

Please cite the original version. 


\section{Occurrence of the moth Cydia pactolana is associated with the spruce canker fungus Neonectria fuckeliana}

\section{Anne Uimari, Kari Heliövaara, Katalin Tuba, Marja Poteri \& Martti Vuorinen}

To cite this article: Anne Uimari, Kari Heliövaara, Katalin Tuba, Marja Poteri \& Martti Vuorinen (2018): Occurrence of the moth Cydia pactolana is associated with the spruce canker fungus Neonectria fuckeliana , Scandinavian Journal of Forest Research, DOI: 10.1080/02827581.2018.1427791

To link to this article: https://doi.org/10.1080/02827581.2018.1427791

View supplementary material ¿

Accepted author version posted online: 11 Jan 2018.

Published online: 29 Jan 2018.

Submit your article to this journal $\asymp$

山 Article views: 11

Q View related articles ¿

View Crossmark data 


\title{
Occurrence of the moth Cydia pactolana is associated with the spruce canker fungus Neonectria fuckeliana
}

\author{
Anne Uimari $\mathbb{1}^{\mathrm{a}}{ }^{\text {, }}$ Kari Heliövaara ${ }^{\mathrm{b}}$, Katalin Tuba ${ }^{\mathrm{c}}$, Marja Poteri ${ }^{\mathrm{a}}$ and Martti Vuorinen ${ }^{\mathrm{a}}$ \\ ${ }^{a}$ Natural Resources Institute Finland, Suonenjoki, Finland; ${ }^{b}$ Department of Forest Sciences, University of Helsinki, Helsinki, Finland; ${ }^{c}$ Institute of \\ Silviculture and Forest Protection, University of Sopron, Sopron, Hungary
}

\section{ABSTRACT}

Several young damaged Norway spruce stands in eastern and central Finland were observed from 2013 to 2016. The damage included trees with heavy resin flow, necrotic foliage, stem and branch cankers and dead trees. Pest identification resulted in the tortricid moth Cydia pactolana whose occurrence was always associated with the presence of the ascomycete pathogen Neonectria fuckeliana. Both the insect and the disease contributed to the extent of the damage, but it is not possible to say in which order they had attacked the trees. Apparently, changed climate has affected the increased occurrence of both the fungus and the moth. However, the characteristics of the insect-fungus interaction and the factors contributing to the coincidences are unknown. Emerging coexistence or potential symbiosis of the two damaging agents is a serious threat for Norway spruce cultivation. Understanding the biology of this fungus-insect interaction is important for controlling them.
ARTICLE HISTORY

Received 18 September 2017

Accepted 9 January 2018

\section{KEYWORDS}

Picea abies; forestry; forest

damage; insects;

ascomycetes; pest

management

\section{Introduction}

Norway spruce [Picea abies (L.) Karsten] is a native tree species in Europe. In North Europe, it is one of the most important trees cultivated for the wood industry as well as for Christmas tree production. Although several pests and diseases can affect Norway spruce, only a few, like the European spruce bark beetle (Ips typographus L.) and the root rot Heterobasidion annosum species complex, have caused continuous and serious damage in Eurasia (Schelhaas et al. 2003; Wermelinger 2004; Honkaniemi 2017). The implications of climate change are suggested to affect forest health in multiple ways (Milada et al. 2011). An important role will be played by insects and pathogens, whose survival, reproduction, distribution and expansion will be dramatically influenced, for example, by the changes in temperature and precipitation (Ayres and Lombardero 2000).

Spruces are used as food plants by the larvae of some moth and butterfly species (Lepidoptera). The spruce bark tortrix, Cydia pactolana (Zeller), is a small (wing span 12$15 \mathrm{~mm}$ ), dark brown tortricid moth that has characteristic whitish figures on the fore wings (Zeller 1840). According to old observations, the moth is known to occur as a relatively common species in most countries of Europe (Trägårdh 1939; Postner 1978). Young Norway spruce and other species of Picea, and occasionally larch (Larix spp.), are used as hosts for the C. pactolana larvae (Bogenschutz 1991; Bland 2014). In average, adult moths have a flight period from the end of May to the end of June during which the oviposition on the bark occurs (Bogenschutz 1991). Larvae penetrate into the bark and bore tunnels leading to resin flow and formation of frass piles which reveal the site of attack. The larvae can kill branches or girdle the whole stem of a small spruce (Bogenschutz 1991; Csoka and Kovacs 1999). In Japan, the scars of a bark moth (C. pactolana ssp. yasudai) have caused heavy resin exudation in planted Abies sachalinensis stands (Hara et al. 2004). Larval diapause lasts from the middle of October to April after which the larvae continue eating for 3 to 5 weeks (Bogenschutz 1991). Pupation occurs in May or June in the opening of the bore holes and after three to 4 weeks adults emerge from the pupa which have partly moved out of the excrement piles (Bogenschutz 1991).

Neonectria fuckeliana (C. Booth) is an ascomycete fungus whose sexual fruiting bodies, perithecia, are present on the bark of an infected tree. The perithecia have a diameter of 200 to $400 \mu \mathrm{m}$ and their colour varies from yellow to orange when young but become red and brown with age (Brayford et al. 2004). In New Zealand and Chile, N. fuckeliana has been connected to a canker disease affecting Pinus radiata and in North America the fungus infects Abies spp. (Schultz and Parmeter 1990, Dick and Crane 2009; Morales 2009). Interestingly, in Europe N. fuckeliana has for a long time been considered mostly a harmless wound invader or weak wound pathogen of conifers (Roll-Hansen and Roll-Hansen 1979; Vasiliauskas and Stenlid 1998). However, recent observations in Finland, Norway and Sweden have confirmed that N. fuckeliana has become a more serious pathogen of Norway spruce causing canker formation, heavy resin flow and, in worst cases, tree death (Lilja et al. 2011; Pettersson et al. 2016; Uimari et al. unpublished data).

In this paper, we describe the evaluation and identification of pest and disease causing organisms in young spruce stands 
abundantly occurring in recent years in eastern and central Finland. The paper describes the novel role of $C$. pactolana as a serious spruce pest in Finland. In addition, this is the first report showing the systematic coexistence of $C$. pactolana and $N$. fuckeliana in damaged Norway spruce stands. Increased simultaneous occurrence of Norway spruce pest and disease problems emphasizes the need of new strategies to prevent and manage damage in young spruce stands.

\section{Materials and methods}

\section{Evaluation of diseased spruce stands}

The locations (GPS coordinates) and ages of stands were recorded. Damaged spruces in the stands were subjected to visual macroscopic examination for the signs of insect infestation and presence of hyphae, fruiting bodies or other indications of fungal growth. In the laboratory, the spruce samples were further studied by microscopy and molecular techniques.

\section{Insect rearing}

Insect-infested spruces (60-80 trees, stand No. 15 Figure 1) were felled and pruned in October 2014. For the winter, the trunk piles were loosely covered with plastic sheets and placed in a storage building (Suonenjoki, Finland) where the temperature was fluctuating with outdoor conditions. Insect rearing started in March 2015. Between 30 and $50 \mathrm{~cm}$ long pieces of insect-infested spruce stems were placed in cloth sacks $(60 \times 40 \mathrm{~cm})$ and covered with dark plastic bags. A transparent glass tube was tied in the opening of each sack. Small cuts were made in the plastic bags to allow air flow and wet paper towels were placed in the sacks to maintain high air moisture. Ten sacks each containing four logs were prepared. The samples were incubated at $20^{\circ} \mathrm{C}$ in the green house for 6 weeks, and the glass tubes were observed daily for the presence of insects. Hatched insects were removed from the tubes for identification.

\section{Identification of C. pactolana}

Species identification of tortricids and especially tortricid larvae can be problematic. Here, the identification of $C$. pactolana larvae was carried out according to Ericson (1960) and Gilligan and Passoa (2014). In addition, the larvae of our Finnish rearings were compared with larvae collected in Hungary. For the comparison, the late instars were examined using both lateral and dorsal views, anal shield, number of small circle of gripping hooks (crochet) on prolegs, head (including shape and size of mandibles), mouthparts and setae of the larvae. The symptoms of damage caused by the larvae were also examined according to Szőcs (1977). The adult moths, reared from the study material, were identified on the basis of the morphological characteristics and genitalia according to Bradley et al. (1973) and Razowski (2003).

\section{Cultivation and identification of $\mathrm{N}$. fuckeliana}

Fungal cultures were isolated and propagated either from the perithecia found on the surface of the infected spruce material or hyphae grown inside the tree. Perithecia were collected under a microscope, dipped into $70 \%$ ethanol for $30 \mathrm{~s}$, rinsed with sterile water for $60 \mathrm{~s}$ and air-dried for $5 \mathrm{~min}$ after which they were placed on potato dextrose agar (PDA) and incubated at $24^{\circ} \mathrm{C}$ for $7-14$ days.

Hyphae growing in the cavities below the bark were sampled with a sterile needle under a microscope and plated on PDA as described above. The morphology of pure fungal cultures derived either from perithecia or hyphae from the infected trees was studied by microscopy and the fungal DNA was isolated with DNeasy Plant Mini Kit (Qiagen, Hilden, Germany) according to the manufacturer's instructions. The ITS region of a ribosomal DNA operon was PCR-amplified with the primers $5^{\prime}$-GGAAGTAAAAGTCGTAACAAGG-3' (ITS5) and 5'-TCCTCCGCTTATTGATATGC-3' (ITS4). PCR reactions contained $30 \mathrm{ng}$ of fungal DNA, $1 \times \mathrm{PCR}$ buffer with $\mathrm{MgCl}_{2}$ (Thermo Fisher Scientific, MA, USA), dNTP mix (200 $\mu \mathrm{M}$ each), 25 pmol forward and reverse primers and 0.5 units DyNAzyme II DNA polymerase (Thermo Fisher Scientific, MA, USA) in a total volume of $50 \mu \mathrm{L}$. The programme consisted 1 cycle of $95^{\circ} \mathrm{C}$ for $3 \mathrm{~min}, 30$ cycles of $95^{\circ} \mathrm{C}$ for $30 \mathrm{~s}$, $58^{\circ} \mathrm{C}$ for $40 \mathrm{~s}, 72^{\circ} \mathrm{C}$ for $40 \mathrm{~s}$ followed by 1 cycle of $72^{\circ} \mathrm{C}$ for 5 $\mathrm{min}$. The amplification product was purified with the QIAquick PCR Purification Kit (Qiagen, Hilden, Germany) and sequenced. The nucleotide sequences were aligned with sequences deposited in the National Centre for Biotechnological Information (NCBI) genebank by using the Basic Local Alignment search Tool to establish identities of the fungal isolates.

\section{Insect trapping}

On 20 May 2015, four traps were placed in a forest (No. 5 in Figure 1) to catch C. pactolana moths directly from their host trees. The spruce stems showing signs of insect infestation (piles of excrements) were loosely covered with a dark plastic sheet for a length of $60-80 \mathrm{~cm}$. Transparent plastic tubes were inserted in the middle of the sheets. The traps were monitored weekly until September 2015.

Pheromone-baited traps for C. splendana (CSALOMON, Budapest, Hungary), containing partly the same substances known to attract the closely related C. pactolana, were tested for moth catching. Six traps were tied to poles between 1.5 and $2.5 \mathrm{~m}$ above the ground on a site infested by C. pactolana (No. 17 in Figure 1) at the beginning of June in 2016. The traps were monitored weekly until the middle of September in 2016.

\section{Results}

\section{C. pactolana infests young spruce stands in eastern} and central Finland

Nineteen planted severely damaged young Norway spruce stands were examined from 2013 to 2016 . The stands were situated within an area of $1.1 \times 10^{5}$ hectares $(280 \mathrm{~km} \times$ $390 \mathrm{~km}$ ) in eastern and central Finland (Figure 1). The age of the infested stands varied from 11 to 22 years with an average of 13 years. In each stand, spruces with dead tops 


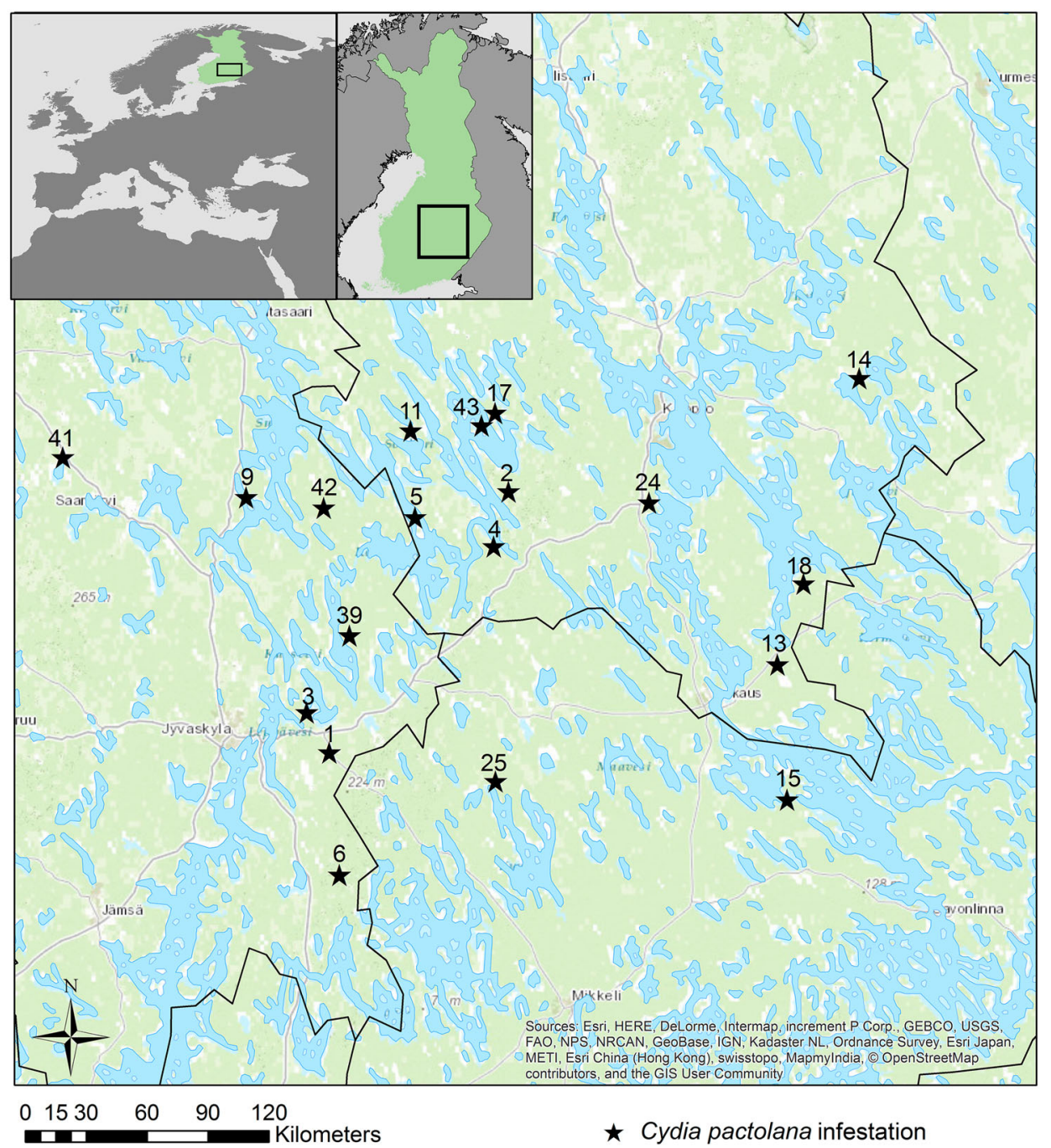

Figure 1. Location of C. pactolana-infested sites. Nineteen sites in eastern and central Finland were evaluated for the damage caused by C. pactolana.

were frequently observed (Figure 2(a)). Also, totally dead trees (5\% in average) were observed. In each stand, insect infestation characterized with heavy stem-covering resin flow and piles of insect excrements were found on bark near the branch whorls, and occasionally the remnants of pupae were visible in the piles (Figure 2(b)). Microscopic analysis revealed larvae either in their fresh feeding tunnels spread out in all directions in the phloem or in the silken tunnels in the case of diapausing larvae (Figure 2(c)).

For species identification, the insects were reared from the larvae-containing logs. Adult moths emerged within 3 weeks. Based on the larval morphology and the adult male genitalia, the moths were identified as C. pactolana (Figures $2(\mathrm{~d}, \mathrm{e})$ ). In addition to the moth, specimens of Glypta parvicaudata Bridgman 1889 (Hymenoptera, Ichneumonidae) were observed in the samples.

Two trials to monitor $C$. pactolana in infested sites were carried out in the summers 2015 and 2016. During the weekly checkings, no insects were observed in the plastic bag traps around infested spruces. However, six individuals were found inside the traps when the experiment was finished in September 2015. In pheromone-baited traps, five
C. pactolana moths were caught in 2016 between 23 June and 6 July.

\section{N. fuckeliana grows in C. pactolana infected spruces}

In all sites infested by C. pactolana, the damaged spruces had dark resin-flowing cankers and dried lateral shoots (Figure 3 (a)). The damage symptoms resembled Neonectria canker disease and closer examination of stem and branch cankers occasionally revealed the presence of perithecia with various shades of red on the bark (Figure 3(b)). Interestingly, the canker areas and the areas infested by C. pactolana mostly co-localized. Microscopic analyses of the wood under the bark in damaged areas showed that the fresh larval tunnels were often heavily resin-filled and sporadically occupied by white fungal hyphae (Figure 3(c)). The same kind of fungal growth was also observed in the older tunnels. Occasionally, saprophytic fungi were found at the entrances of the tunnels but under a microscope, they were not encountered deeper in the tunnels and thus, were not isolated for further analysis. Perithecia and the tunnel-grown white hyphae were used for propagation of fungal pure cultures 

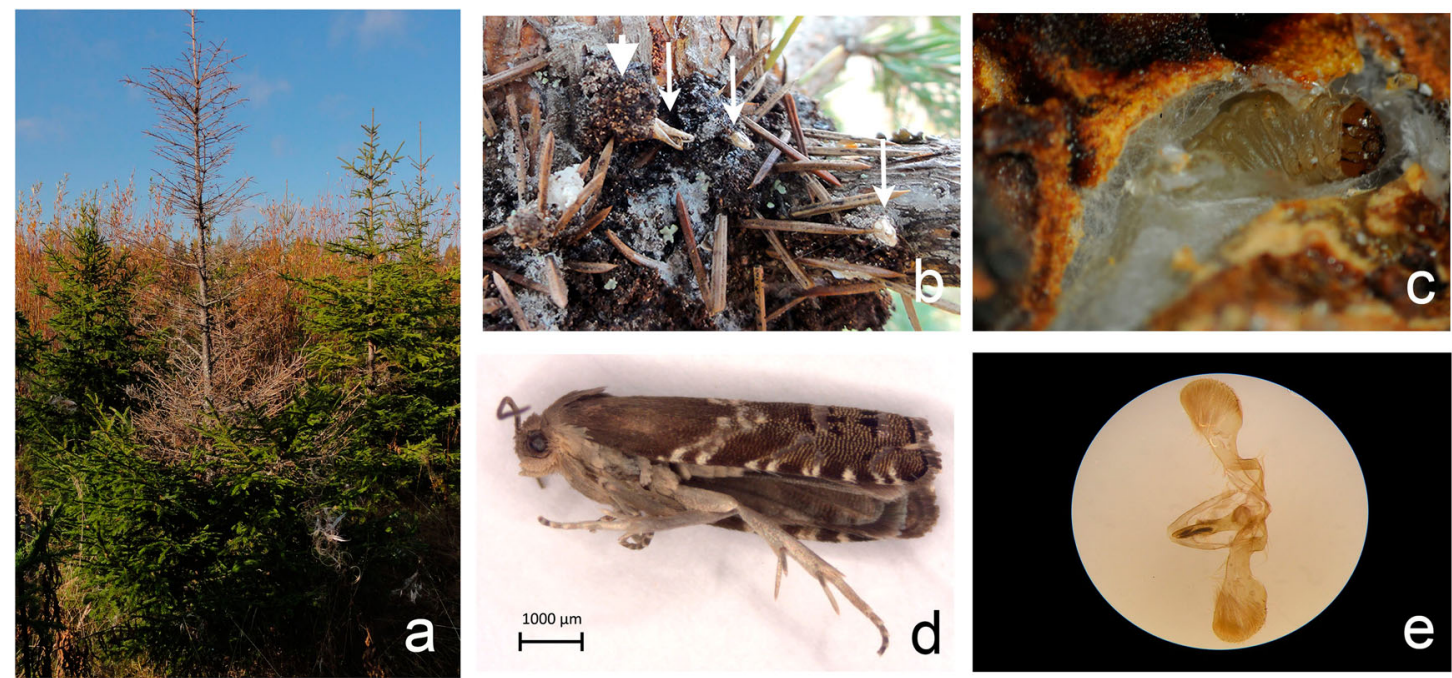

Figure 2. C. pactolana in an 11 years old Norway spruce stand; (a) a dried tree top caused by feeding by C. pactolana larvae, (b) a frass pile (arrow head) and old pupae (arrows) revealing C. pactolana infestations, (c) a C. pactolana larva in a tunnel under the spruce bark, (d) C. pactolana moth and (e) the male genitalia of C. pactolana.
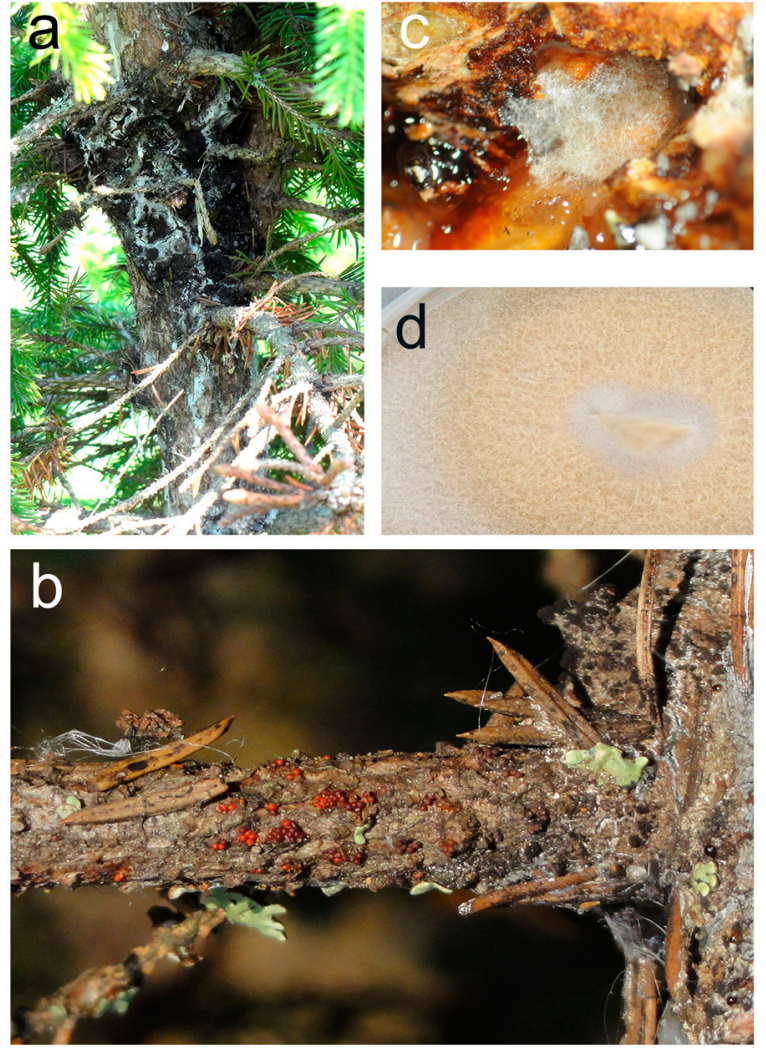

Figure 3. Characteristics of N. fuckeliana; (a) dried branches and resin flow in a canker area of $N$. fuckeliana infected spruce stem, (b) ascospore-containing N. fuckeliana perithecia on a bark of the fungus-infected branch, (c) N. fuckeliana hyphae growing in a feeding tunnel of C. pactolana and (d) a pure culture of N. fuckeliana isolated from an infected Norway spruce.

(Figure 3(d)). On the basis of the DNA-analysis, the fungus was confirmed to be $N$. fuckeliana.

\section{Discussion}

Our paper describes the role of the spruce bark tortrix C. pactolana as a new potentially serious threat to the health of the young Norway spruce forests in Finland. In Central Europe, C. pactolana is recognized as a serious pest of conifer forests and Christmas tree plantations (Postner 1978; Tuba and Kelemen 2015). The outbreaks of the species in Europe often occur after dry years and other exceptional weather condition, or after damages caused by game animals (Bogenschutz 1991). C. pactolana has been reported in almost all biogeographical provinces of Finland (Kullberg et al. 2001). However, the species has not been previously connected with extensive forest damage in Finland and, at present, there is no specific monitoring programme of $C$. pactolana. Based on the observation from damaged forest stands, C. pactolana was abundant in the years 2013 and 2014, whereas, our traps caught only a few adult moths in summers 2015 and 2016. Among known parasitoids, for C. pactolana are Ascogaster quadridentata (Braconidae), Glypta tenuitarsis (syn. Glypta parvicaudata Bridgman 1889), G. incisa (Ichneumonidae) and Pimpla turionellae (Ichneumonidae) (Bogenschutz 1991, Šedivý 2001). We found abundant amounts of $G$. parvicaudata when C. pactolana was reared from the infected logs. In samples where there were a few individuals of $C$. pactolana, the number of developed G. parvicaudata was higher than in the samples which produced abundant amounts of the moth. Thus, parasitism may affect the C. pactolana population size in Finland.

C. pactolana is especially a pest of young Norway spruces (Bogenschutz 1991; Bland 2014). Heavily moth-infested trees will partly or totally die because of the disturbed transportation of water and nutrients by the larvae feeding tunnels. In less severe attacks, only branches next to the feeding tunnels dry out. Recently, N. fuckeliana has been identified as the causal agent of canker disease of Norway spruce in several countries in northern Europe (Lilja et al. 2011). N. fuckeliana induces canker formation and increases the resin production and thereby decreases the growth and quality of the infected tree. The fungus is suggested to spread mainly by the sexual ascospores produced in perithecia present on the bark of trees (Vasiliauskas and Stenlid 1997; 
Crane et al. 2009). Dispersal of the spores most probably takes place by rain drops and splashing water (Crane et al. 2009). Occasionally, N. fuckeliana has been found as a secondary pest after C. pactolana infestation (Postner 1978). Since $N$. fuckeliana and C. pactolana were both present in the studied stands, the severe tree damage reported in this paper most probably resulted from the coexistence of the moth and the fungus. However, concerning the forest damage reported here, it is not known in which order the two organisms have attacked the trees and how they interact with each other. Interestingly, the ecology of many insect species is strongly affected by their bacterial and fungal symbionts. Insect associations with fungi may be casual or highly specific and obligate (McCulloch Martin 1992; Frago et al. 2012). Many nutritional substrates of insects, e.g. in wood (xylem) are at very low levels and do not provide essential nutrients for the insect. However, in many cases fungal symbionts enable their hosts to feed on nutritionally imbalanced diets (Arnold and Lewis 2005).

The stands in eastern and central Finland were in areas extensively used for the cultivation of Norway spruce. Thus, the abundant supply of host species at a suitable development stage and growing in a preferred biotype may have affected the regional pest incidences. In addition, changing climate altering seasonal temperature and the amount of precipitation has most probably increased the occurrence and survival of both the pest and the pathogen in Finland.

\section{Conclusions}

This paper describes for the first time the tortricid moth C. pactolana as a causative agent for Norway spruce forest damage in Finland. Interestingly, N. fuckeliana fungus, also damaging spruce forests, coincides with C. pactolana. At the moment, the factors supporting the coexistence of the insect and the pathogen in the damaged sites are unknown. Future investigations will increase the understanding of the interaction between the moth, the fungus and Norway spruce supporting development of new tools for pest control.

\section{Acknowledgements}

We thank Drs. Juhani Itämies, Antti Pouttu and Tiina Ylioja for comments on the manuscript.

\section{Disclosure statement}

No potential conflict of interest was reported by the authors.

\section{ORCID}

Anne Uimari (D) http://orcid.org/0000-0001-7136-685X

\section{References}

Arnold E, Lewis LC. 2005. Ecology and evolution of fungal endophytes and their roles against insects. In: Vega FE, Blackwell M, editors. Insectfungal associations: ecology and evolution. New York: Oxford University Press; p. 74-96.
Ayres MP, Lombardero MJ. 2000. Assessing the consequences of global change for forest disturbance from herbivores and pathogens. Sci Total Environ. 262:263-286.

Bland KP. 2014. Systematic treatment of species of olethreutinae. In: Bland KP, editor. Moths and butterflies of Great Britain and Ireland. Part 2. Vol. 5, Tortricidae, Olethreutinae. Leiden: Brill; p. 6-241.

Bogenschutz H. 1991. Eurasian species in forestry. In: van der Geest LPS, Evenhius HH, editors. Tortricid pests: their biology, natural enemies, and control. World crop pests. Vol. 5. Amsterdam: Elsevier; p. 673-709.

Bradley JD, Tremewan WG, Smith A. 1973. British Tortricoid Moths: Cochylidae and Tortricidae: Tortricinae. London: The Ray Society.

Brayford D, Honda BM, Mantiri FR, Samuels GJ. 2004. Neonectria and Cylindrocarpon: the Nectria mammoidea group and species lacking microconidia. Mycologia. 96:572-597.

Crane P, Hopkins A, Dick M, Bulman L. 2009. Behaviour of Neonectria fuckeliana causing a pine canker disease in New Zealand. Can J For Res. 39:2119-2128.

Csoka G, Kovacs T. 1999. Xylophagous insects. Budapest: Forest Research Institute.

Dick MA, Crane PE. 2009. Neonectria fuckeliana is pathogenic to Pinus radiate in New Zealand. Australas Plant Dis Notes. 4:12-14.

Ericson R. translator. 1960. Unpublished English translation ofSwatschek B. 1958. Die larvalsystematik der Wickler (Tortricidae und Carposinidae). Abhandlungen Zur Larvalsystematik der Insekten, 3rd ed. Berlin: Akademie-Verlag.

Frago E, Dicke M, Charles H, Godfray J. 2012. Insect symbionts as hidden players in insect-plant interactions. Trends Ecol Evol. 27:705-711.

Gilligan TM, Passoa SC. 2014. Leplntercept - an identification resource for intercepted Lepidoptera larvae. [accessed 2017 March 22]. http:// idtools.org/id/leps/lepintercept/morphology.html.

Hara H, Tokuda S, Akimoto M. 2004. Heavy resin exudation and tree mortality found in todo-fir (Abies sachalinensis) stands during 1997-2000 in Hokkaido (Japan). Bulletin Hokkaido Forestry Research Institute. 41:1525. Japanese (English summary).

Honkaniemi J. 2017. Integrating mechanistic disturbance models and stand dynamics of Norway spruce [dissertation]. Helsinki: University of Helsinki.

Kullberg J, Albrecht A, Kaila L, Varis V. 2001. Checklist of Finnish Lepidoptera. Sahlbergia. 6:45-190.

Lilja A, Rytkönen A, Napola M-L, Napola J, Talgo V, Poteri M, Hantula J. 2011. Neonectria-sieni, uusi koropatogeeni kuusella? [The Neonectria fungus - a new canker pathogen in spruce?]. Taimiuutiset. 3:21-23. Finnish.

McCulloch Martin M. 1992. The evolution of insect-fungus associations: from contact to stable symbiosis. Amer Zool. 32:593-605.

Milada M, Schaicha H, Bürgib M, Konolda W. 2011. Climate change and nature conservation in central European forests: a review of consequences, concepts and challenges. For Ecol Manage. 261:829-843.

Morales RR. 2009. Detección de Neonectria fuckeliana en Chile, asociado a cancros y malformaciones fustales en plantaciones de Pinus radiata [Detection of Neonectria fuckeliana in Chile associated to stem cankers and malformation in Pinus radiate plantations]. Bosque. 30:106-110. Spanish (English summary).

Pettersson M, Frampton J, Rönnberg J, Talgø V. 2016. Neonectria canker found on spruce and Fir in Swedish Christmas tree plantations. Plant Health Prog. 7:202-205.

Postner M. 1978. Laspeyresiini. In: Schwenke W, editor. Die Forstschädlinge Europas. 3rd ed. Hamburg: Paul Parey; p. 89-109. (German).

Razowski J. 2003. Tortricidae of Europe. Vol 2. Olethreutinae. Bratislava: Slamka.

Roll-Hansen F, Roll-Hansen JR. 1979. Microflora of sound-looking wood in Picea abies stems. Eur J Forest Pathol. 9:308-316.

Schelhaas M-J, Nabuurs GJ, Schuck A. 2003. Natural disturbances in the European forests in the 19th and 20th centuries. Glob Chang Biol. 9:1620-1633.

Schultz ME, Parmeter JR. 1990. A canker disease of Abies concolor caused by Nectria fuckeliana. Plant Dis 74:178-180.

Šedivý J. 2001. Contribution to the taxonomy and knowledge of hosts of ichneumonids (Hymenoptera: Ichneumonidae). Klapalekiana. 37:59-69. 
Szőcs J. 1977. Lepidoptera-aknák és -gubacsok: Hyponomia et cecidia Lepidopterorum. Fauna Hungariae. 125:1-424. Hungarian.

Trägårdh I. 1939. Sveriges skogsinsekter. Stockholm: Hugo Gebers Förlag. Swedish.

Tuba K, Kelemen G. 2015. Insects causing plant protection problems on Christmas tree plantations in Hungary. NIBIO BOOK 1:26.

Vasiliauskas R, Stenlid J. 1997. Population structure and genetic variation in Nectria fuckeliana. Can J Bot. 75:1707-1713.
Vasiliauskas R, Stenlid J. 1998. Fungi inhabiting stems of Picea abies in a managed stand in Lithuania. For Ecol Manage. 109:119-126.

Wermelinger B. 2004. Ecology and management of the spruce bark beetle Ips typographus - a review of recent research. For Ecol and Manage. 202:67-82.

Zeller PC. 1840. Ueber die Schmetterlingsarten in Ratzeburg's ForstInsecten. 2. Theil 1840. Entomologische Zeitung. 1:185-192. German. 